\title{
IGNEOUS ROCKS IN THE PROTEROZOIC PLATFORM OF EASTERN NORTH GREENLAND
}

\author{
Hans F. Jepsen and Feiko Kalsbeek
}

The Proterozoic sandstones of the Inuiteq Sø Formation (Jepsen, 1971) and the Norsemandal Sandstone (Adams \& Cowie, 1953) contain numerous sills, sheets and dykes of dolerites and other intrusive rocks. Locally, the intrusions may make up 75 per cent of the total section along some fjord walls. The sequence is overlain by basaltic volcanics, locally up to $1300 \mathrm{~m}$ thick. The igneous rocks have been the main object of our field work and they are briefly described below. The intrusive rocks have been studied earlier by Koch (1925), Ellitsgaard-Rasmussen (1950) and Jepsen (1969); the occurrence of basaltic volcanics was reported and mapped by the Greenarctic Consortium in 1969 (personal communication to GGU).

\section{The intrusive rocks}

Three types of intrusive rocks have been distinguished: (1) Dolerites, (2) Red granophyric rocks and (3) Silicic rocks - named 'flow breccia' by Ellitsgaard-Rasmussen (1950). The three rock types seem to be more or less contemporaneous although intersections between them are common. For example, the flow breccia sheets both cut and are cut by dolerite sheets and both may contain inclusions of the other. The dolerites are by far the most common.

The sediments into which these rocks intruded have been described by J. D. Collinson (this report) and provisionally subdivided into a lower sandstone formation (the Inuiteq Sø Formation) and an overlying upper sandstone formation (which includes the Norsemandal Sandstone). Both formations contain intrusions although they seem to be more numerous in the lowest unit. If the intrusive rocks are all of roughly the same age, they must thus be younger than most or all of the sandstones below the overlying basalts.

$\mathrm{Rb}-\mathrm{Sr}$ age determinations now being carried out on material collected last summer show that the rocks were intruded $c .1250 \mathrm{~m}$.y. ago. Earlier K-Ar age determinations on two dolorite sills from the Midsommersø region have given ages of $988 \pm 20$ m.y. and $799 \pm 68$ m.y. (Henriksen \& Jepsen, 1970).

\section{The dolerites}

Dolerites of quartz-tholeiitic composition (Jepsen, 1969), form large sills as well as 
steeply dipping sheets and dykes. The three intrusion types commonly pass into each other. Sills are the most common and range in width up to several hundreds of metres.

The dolerites of the major sills show a crudely layered structure, due to crystal settling during their consolidation. The sills have fine-grained borders towards the sandstone. Above the bottom chill, the lower part of the sills consists of dark cumulates mainly of plagioclase and pyroxene (often gravel weathering), grading upwards into normal grey dolerite. Near the top, the dolerites commonly contain a reddish granophyric matrix, the origin of which is not clear.

Probably, the granophyric matrix formud during the later stages of differentiation, but preliminary Sr-isotope evidence shows that contamination with crustal material also played an important role.

Sandstone inclusions in dolerite are very rare. The sandstones bordering major dolerite sills are often not visibly affected. On the other hand, sandstones caught between dolerite sills may show clear columnar jointing like the intrusive rocks themselves.

\section{The red granophyric rocks}

In hand sample the red granophyric rocks are reminiscent of the red granophyric matrix found near the top of many dolorite sills, but in the former, the amount of granophyric material dominates over the dark minerals.

These red granophyric rocks form sheets and dykes up to several tens of metres wide. The intrusions invariably have dark doleritic borders, 1-2 $\mathrm{m}$ wide, which have chilled borders towards the sandstones but grade into the granophyric rocks over a short distance. Quartzite inclusions have occasionally been found in the granophyric rocks.

An eleven-point $\mathrm{Rb}-\mathrm{Sr}$ whole-rock isochron age of $1230 \pm 25$ m.y. $\left(\lambda^{87} \mathrm{Rb}=1.42 \times 10^{-11} \mathrm{y}^{-1}\right)$ has been obtained. The initial ${ }^{87} \mathrm{Sr} /{ }^{86} \mathrm{Sr}$ ratio of this isochron $(0.7129 \pm 7)$ is much higher than values obtained for dolerite samples $(0.703-0.705)$. This indicates that the granophyric rocks are not just late differentiates of the basic magma that formed the dolerites. They may have derived by anatexis of crustal rocks or from the basic magma through massive contamination with crustal material.

\section{The silicic intrusions}

Sheets and sills, up to $50 \mathrm{~m}$ wide, of pink or yellow, sometimes brick-red, very fine-grained, almost quartzitic rocks intrude into the sandstones and older dolerite intrusions. Commonly the rock contains numerous inclusions of white quartzite, dolerite and sandstone, which locally may make up more than 50 per cent of the rock.

Like the red granophyric rocks, the silicic intrusions nearly always have dolerite borders. It seems possible that the silica-rich magma intruded into not yet solidified dolerite sheets and dykes, which would explain the presence of the dolerite borders along nearly all these sheets.

Based on earlier petrographic and chemical evidence (Jepsen, 1969), these very unusual rocks are thought to have been derived from sandstone, mobilised at depth by the thermal effect of large amounts of basic magma. At one locality, mobilisation of sandstone near a large dolerite sill could be seen to have taken place on a small scale. 
To a certain extent, $\mathrm{Sr}$-isotope measurements support this hypothesis. The silicic rocks have even higher initial ${ }^{87} \mathrm{Sr} /{ }^{86} \mathrm{Sr}$ ratios than the granophyric rocks $(0.725-0.738)$, but lower than sandstone samples measured $(0.764-0.781)$. Therefore, if they have been derived by mobilisation of sandstone, they must have exchanged some $\mathrm{Sr}$ with the doleritic magma. High initial ratios in the dolerites that border the silicic rocks $(0.706-0.714)$ support this idea.

\section{The basalts}

The basalts form a well-defined formation in J. C. Christensen Land and Mylius-Erichsen Land, overlying the sandstones of the Inuiteq Sø Formation and the upper sandstone formation. The basalts are capped by the basal sandstone of the Campanuladal Formation (Adams \& Cowie, 1953; Clemmensen, this report). Their maximum thickness, measured in central Mylius-Erichsen Land (Zig-Zag Dal), is c. $1300 \mathrm{~m}$. From here, the thickness decreases both towards the east (c. $500 \mathrm{~m}$ in Norsemandal, 100-200 m near Campanuladal) and towards the west $(600-800 \mathrm{~m}$ in central J. C. Christensen Land; $100-200 \mathrm{~m}$ at the south-east coast of Independence Fjord). North-west of Independence Fjord, the basalt formation has not been found.

In J. C. Christensen Land a series of at least three flows, with a composite thickness of some $100 \mathrm{~m}$, has pale reddish colours. Preliminary chemical analysis of the rocks indicates a rhyolitic to trachytic composition. Such rocks have not yet been recognised with certainty elsewhere in the area.

An attempt to determine the age of the volcanic rocks has not been succesful. $\mathrm{Rb}-\mathrm{Sr}$ measurements do not give isochrons. Until further analyses are available, nothing definitive can be concluded regarding the age relationship between the intrusive rocks and the basalts. However, we think that the stratigraphic position of the basalts makes it likely that they are contemporaneous and genetically related with the underlying dolerite intrusions.

Detailed sections were measured through the basalt formation in central Mylius-Erichsen Land (Zig-Zag Dal) and eastern Mylius-Erichsen Land (Norsemandal).

The lowest part of the basalts (100-200 m) consists of strongly altered (spilitic?) rocks, with local development of pillow structures, suggesting submarine effusion of the basalts. In this lower part, the flows are rather thin, generally 1-5 m. In the Norsemandal section, $c .35$ such flows could be recognised. The contact between the lower basalts and the underlying sandstones is sharp and concordant; the sandstones have been remarkably little affected by the overriding lava flows.

Higher up in the succession, the basalts are fresher and form much thicker flows, up to $c$. $100 \mathrm{~m}$. The flows generally consist of fine-grained massive basalt with clear columnar jointing in the lower part, and grade upwards into strongly vesicular and amygdaloidal rock filled with calcite, quartz, prehnite etc. In the Zig-Zag Dal section $c$. 30 of these thicker basalt flows were found. Most of the flows are aphyric and non-characteristic, but a few are characterised by their phenocryst content (plagioclase, sometimes green coloured by alteration), or their colour, or a specific development of columnar jointing. Such flows can be used to correlate different sections. In this way it was found that in Norsemandal the upper $c .400$ $\mathrm{m}$ of the Zig-Zag Dal profile is missing. The upper flow in the Norsemandal profile was eroded to a different depth at different places, suggesting that the lack of these $400 \mathrm{~m}$ basalt 
is due to erosion rather than to non-deposition in this part of the area. The sandstones overlying the basalts, however, do not contain basalt pebbles.

At several levels volcanic ash layers have been found. In the Zig-Zag Dal section, an up to $60 \mathrm{~m}$ thick ash layer (c. $500 \mathrm{~m}$ below the top of the basalts) covers an irregular topography in the underlying flows. In the Norsemandal section, ash layers have been found at several levels. Here, a sequence of flows from the middle part of the basalt formation is lacking, probably due to periods of erosion alternating with periods of volcanic activity. The thinning of the basalts seems thus to be due both to post-basaltic and inter-basaltic erosion.

In the Norsemandal profile, the lower (submarine?) basalts are separated from the overlying fresh (subaerial?) basalts by some $10 \mathrm{~m}$ of sediment, mainly stromatolitic dolomite with some shale. Such sediments occur also further south, locally up to $40 \mathrm{~m}$ thick, but have not been found in the Zig-Zag Dal section.

The Zig-Zag Dal section may represent the most complete section of basalts. Here they are thickest and there is little evidence of inter-basaltic sedimentation, with clear evidence of inter-basaltic erosion existing only at one level. The rather restricted number of flows in this section (some 50 flows), together with the scarce evidence of inter-basaltic erosion, suggests that the volcanic activity lasted only for a relatively short period, or a few short periods. If the volcanism lasted for one million years, each of the $c$. 50 flows would have been at the surface for some 20000 years on average, and erosion, especially of the vesicular tops, would probably have been widespread.

\section{References}

Adams, P.J. \& Cowie, J.W. 1953: A geological reconnaissance of the region around the inner part of Danmarks Fjord, Northeast Greenland. Meddr Grønland 111,7, 24 pp.

Ellitsgaard-Rasmussen, K. 1950: Preliminary report on the geological field work carried out by the Danish Peary Land Expedition in the year 1949-50. Meddr dansk geol. Foren. 11, 589-595.

Henriksen, N \& Jepsen, H. F. 1970: K/Ar age determinations on dolerites from southern Peary Land, North Greenland. Rapp. Grønlands geol. Unders. 28, 55-58.

Jepsen, H. F. 1969: Basiske intrusiver i det sydlige Peary Land og deres geologiske milieu. Unpubl. thesis, Univ. Aarhus, Denmark.

Jepsen, H. F. 1971: The Precambrian, Eocambrian and early Palaeozoic stratigraphy of the Jørgen Brønlund Fjord area, Peary Land, North Greenland. Bull. Grønlands geol. Unders. 96 (also Meddr Grønland, 192,2) 42 pp.

Koch, L. 1925: The geology of North Greenland. Amer. J. Sci. (5), 9, 271-285. 